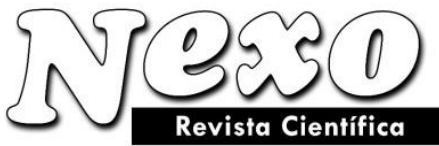

ISSN-E 1995-9516

Universidad Nacional de Ingeniería COPYRIGHT @ (UNI). TODOS LOS DERECHOS RESERVADOS http://revistas.uni.edu.ni/index.php/Nexo https://doi.org/10.5377/nexo.v34i04.12687

\title{
Temporal and spatial changes of macrobenthos communities in south east shores of the Caspian sea
}

\section{Cambios temporales y espaciales de las comunidades macrobentos en las orillas surestes del mar Caspio}

\author{
Nadia Javandel ${ }^{1, *}$, Maryam Akhoundian ${ }^{2}$ \\ ${ }^{1}$ Department of Marine and environmental science, University of Mazandaran, Babolsar, Iran. \\ ${ }^{2}$ Department of Marine Biology, Faculty of Marine and Environmental Science, University of \\ Mazandaran, Babolsar, Iran \\ *nadiajavan3@gmail.com
}

(recibido/received: 21-mayo-2021; aceptado/accepted: 17-julio-2021)

\begin{abstract}
In this research, Sampling of macrobenthos of Mazandaran beaches was performed in 7 stations at two depths of 5 and 10 meters during four seasons in 2020 using a grab with 8 replications in each station. In this study, a total of 10472 individuals were counted, which belonging to 22 species from 13 families. The highest frequency of macrobenthos $(648 \pm 170.79)$ was observed in spring and the highest amount of biomass ( $36.21 \pm 2.5 \mathrm{gr} / \mathrm{m} 2$ ) was observed in winter. Moreover, the highest prevalence of macrobenthos predominant groups during the sampling period was observed in Bivalves (40\%), Crustaceans (36\%), Annelids (22\%) and Gastropoda (2\%), respectively. The results of PERMANOVA analysis showed that the effect of two factors of season and depth impacted the biomass, abundance, species richness, species composition and community structure of macrobenthos significantly. Furthermore, the results showed that with increasing the depth from 5 to 10 meters, macrobenthos abundance increased by 4, 2, 1 and 9 times in spring, summer, autumn and winter, respectively. Moreover, increase in depth from 5 to $10 \mathrm{~m}$, the values of biomass and species richness have increased. In according to these results, it can be concluded that biomass and diversity index of macrobenthos communities change considerably in different seasons and depths. Therefore, natural changes of these variables should be considered when using these macrobenthos communities to assess the impact of environmental factors.
\end{abstract}

Keywords: Macrobenthos, Biomass, Abundance, Caspian Sea.

\section{RESUMEN}

En esta investigación, el muestreo de macrobentos de las playas de Mazandaran se realizó en 7 estaciones a dos profundidades de 5 y 10 metros durante cuatro temporadas en 2020 utilizando una cuchara con 8 
réplicas en cada estación. En este estudio se contó un total de 10472 individuos, los cuales pertenecen a 22 especies de 13 familias. La mayor frecuencia de macrobentos $(648 \pm 170,79)$ se observó en primavera y la mayor cantidad de biomasa $(36,21 \pm 2,5 \mathrm{gr} / \mathrm{m} 2)$ se observó en invierno. Además, la mayor prevalencia de grupos predominantes de macrobentos durante el período de muestreo se observó en Bivalvos (40\%), Crustáceos (36\%), Anélidos (22\%) y Gastropoda (2\%), respectivamente. Los resultados del análisis de PERMANOVA mostraron que el efecto de dos factores de la estación y la profundidad afectó significativamente la biomasa, la abundancia, la riqueza de especies, la composición de especies y la estructura de la comunidad de macrobentos. Además, los resultados mostraron que al aumentar la profundidad de 5 a 10 metros, la abundancia de macrobentos aumentó 4, 2, 1 y 9 veces en primavera, verano, otoño e invierno, respectivamente. Además, al aumentar la profundidad de 5 a $10 \mathrm{~m}$, se han incrementado los valores de biomasa y riqueza de especies. De acuerdo con estos resultados, se puede concluir que la biomasa y el índice de diversidad de las comunidades de macrobentos cambian considerablemente en diferentes estaciones y profundidades. Por lo tanto, se deben considerar los cambios naturales de estas variables al utilizar estas comunidades de macrobentos para evaluar el impacto de los factores ambientales.

Palabras clave: Macrobentos, Biomasa, Abundancia, Mar Caspio.

\section{INTRODUCTION}

The Caspian Sea is considered as the largest lake in the world. It is located between Iran, Turkmenistan, Kazakhstan, Russia and Azerbaijan. The length of the Caspian Sea from north to south is about 1200 kilometers and its width in the widest parts in the north is 554 kilometers and in the narrowest part it is about 302 kilometers (Negarestan and Hashemi, 2020). The Northern Caspian only is very shallow and contain the Caspian shelf. The Southern Caspian is the deepest, with oceanic depths of over 1,000 meters, considerably exceeding the depth of other regional seas, like the Persian Gulf. The Middle of Caspian and the Southern Caspian account for 33\% and 66\% of the total water volume, respectively (Jalili et al., 2010). The northern part of the Caspian Sea freezes in the winter, and in the coldest winters ice made in the south. The Caspian Sea is the remnant of the Tethys Ocean, and the salinity of this sea decreased sharply in Ploston that led to a reduction in biodiversity and evolution of native species (Kowsari et al., 2010). Among the native species, for example, we can mention Phoca caspica species and six species of sturgeon (Mirzajani et al., 2005).

Most of the creatures in the Caspian Sea are invertebrates (77\%). A total of 476 invertebrate species have been identified in the Caspian Sea, $46 \%$ of which are native to the Caspian Sea and more than $20 \%$ of which are non-native. Most of them are including benthic communities (Ghasemi et al., 2016; Farshchi et al., 2018). These organisms are the most important food source for fish. Benthic communities are suitable for long-term comparative research because many species of these communities are sedentary (Chen et al., 2010; Briggs et al., 2017). They are also relatively long-lived and show the effect of environmental changes over time (Nicolau et al., 2015).

Diversity in physiological tolerance, life cycle strategies, type of nutrition and on nutritional interactions in macrobenthos communities make these communities suitable for assessing environmental conditions (Sánchez-Moyano et al., 2010; Zhang et al., 2013; Mulik et al., 2020). In addition, these organisms play an important functional role in disrupting sediments, providing nutrients to higher nutrient groups, as well as 
habitat creation (Farshchi et al., 2020). Also, macrobenthos play an important role as secondary producers in the seas and play a key role in the food chain (Sowa et al., 2020).

Generally, the pattern distribution of macrobenthos are related to environmental factors such as tidal currents, depth, Nutrients, sediment type, amount of organic matter and flow velocity (Tajri et al., 2014). Usually, the abundance and biomass of the benthic communities show almost significant changes with time and space. For example, in the study carried out by Sharbati et al. (2013) on the abundance and biomass of macrobenthos communities in the coastal waters of the southeastern Caspian Sea, the highest abundance of predominant community of benthos was reported in the Gastropoda, Foraminifera, Polychaetes and bivalves, respectively (Asghari et al., 2014). In this study, the highest abundance was determined in summer and the lowest abundance in autumn, as well as the highest biomass in summer and the lowest biomass in spring. The research results of Borhani Jelodar et al. (2010) on the relationships between the dominant macrobenthos communities and some environmental parameters in the southern part of the Caspian Sea showed that in different seasons the polychaetes has the highest population share among the dominant benthic classes. In this study, the highest abundance was observed in summer which mainly related to Streblospio species of polychaetes (Angulo-Preckler et al., 2017).

Ghasemi et al. (2016) studied on macrobenthos Gorgan Bay and indicated that the dominance of the Streblospio community (Kosari et al., 2009). In another study by Jalili et al., (2010) on macrobenthos in Bandar Anzali in Gilan Province the macrobenthos fauna of the southwestern part of Wetland was carried out. In this study, the highest abundance of macrobenthos are shown in spring and the highest amount of biomass was observed in autumn (Sharbati et al., 2013). In another study by Kowsari et al. on abundance and biomass of Caspian Sea benthos in Mazandaran province was performed (Borhani Jelodar et al, 2010). The highest abundance of benthos communities during length is related to Polychaetes, Oligochaeta, Bivalves, Crustaceans and Insecta are reported, respectively. In this study, the highest abundance in summer and the lowest abundance was determined in autumn (Kosari et al , 2021).

As mentioned, spatial and temporal changes of macrobenthos can be dependent on environmental conditions. Part of the environmental conditions change with the change of seasons and part of it is also affected by human activities. Since benthic communities are used in environmental assessment studies, the study of natural changes of these communities and the effect of environmental factors is very important to them. Therefore, in the present study, spatial and temporal changes in abundance, biomass and the species richness of macrobenthos species of in the Caspian Sea in 2 depths (5 and $10 \mathrm{~m}$ ) and 4 seasons were studied.

\section{MATERIAL AND METHODS}

The present study on the coasts of the city of Mazandaran province, seasonally from spring to winter (May, August, November, February) in 7 stations in 2020 (Table 1 and Figure 1). Since the studied stations were located near the hot water outlet of the cooling system of Mazandaran power plant, with ambient temperature monitoring, the stations were selected in such a way that they would not be affected by hot water. For sampling of macrobenthos communities, sampling with Van Veen model was used. 
Table 1- Geographical location of the stations and depth of stations during the period of study on the shores of Mazandaran city per year 2020

\begin{tabular}{|c|c|c|c|}
\hline Station & Depth & Latitude & Longitude \\
\hline 1 & 5 & $4906^{\prime} 12.88^{\prime \prime} \mathrm{E}$ & $37038^{\prime} 50.69^{\prime \prime} \mathrm{N}$ \\
\hline 2 & 5 & $4905^{\prime} 25.95^{\prime \prime} \mathrm{E}$ & $37039^{\prime} 1.80^{\prime \prime} \mathrm{N}$ \\
\hline 3 & 10 & $4905^{\prime} 31.01^{\prime \prime} \mathrm{E}$ & $37039^{\prime} 10.76^{\prime \prime} \mathrm{N}$ \\
\hline 4 & 10 & $4905^{\prime} 49.33^{\prime \prime} \mathrm{E}$ & $37039^{\prime} 6.09^{\prime \prime} \mathrm{N}$ \\
\hline 5 & 10 & $4905^{\prime} 49.99^{\prime \prime} \mathrm{E}$ & $37039^{\prime} 6.04^{\prime \prime} \mathrm{N}$ \\
\hline 6 & 10 & $4906^{\prime} 51.04^{\prime \prime} \mathrm{E}$ & $37039^{\prime} 5.80^{\prime \prime} \mathrm{N}$ \\
\hline 7 & 10 & $4906^{\prime} 17.46^{\prime \prime} \mathrm{E}$ & $37038^{\prime} 59.65^{\prime \prime} \mathrm{N}$ \\
\hline
\end{tabular}

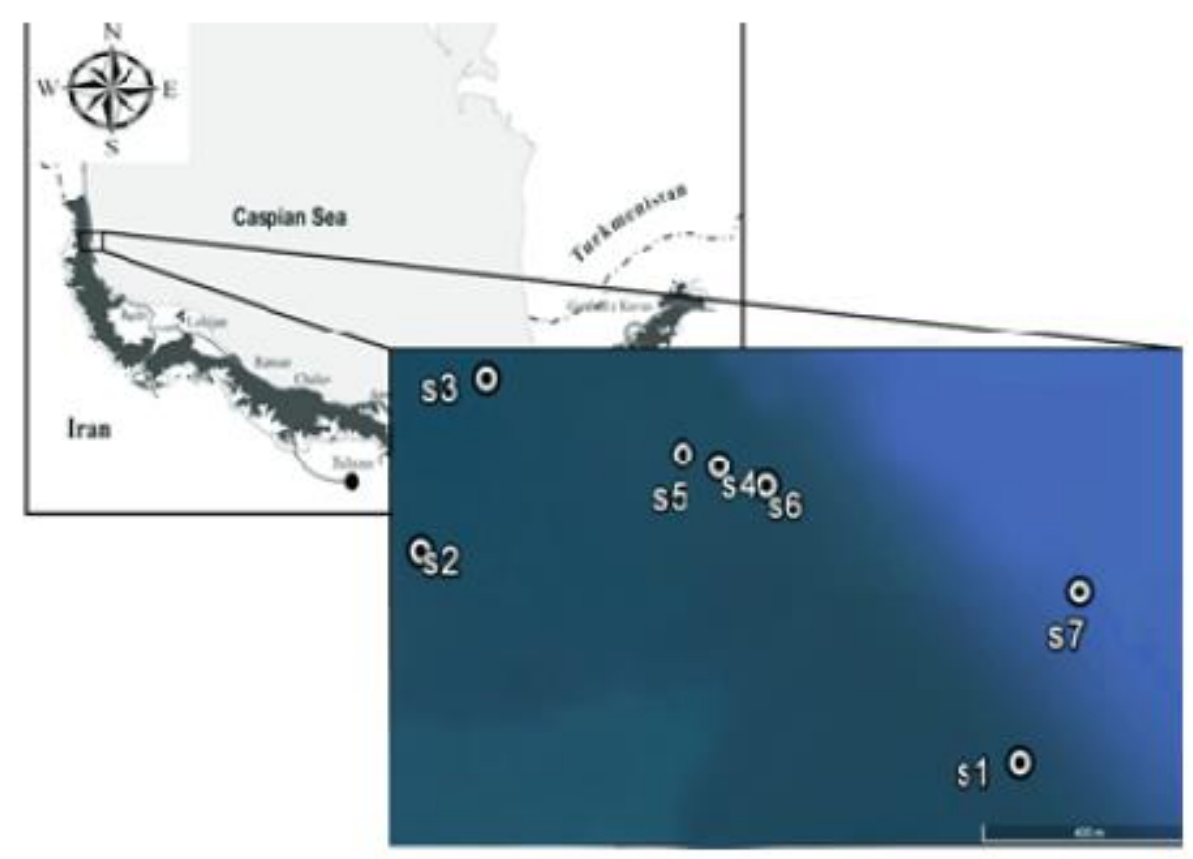

Figure 1- The studied area and location of sampling stations on the shores of Mazandaran city per 2020 year

To determine the number of replicates in each station, in the first sample in Spring, 10 replicates per station were taken. Then the number of species in each replicates was determined and then the standard error of each iteration was calculated from the data mean calculation. In the next step, accuracy index was calculated.

Finally, the number of replicates was averaged and the obtained number as the number of replicates in sampling. In the present study, the appropriate number of replications for sampling in the stations were obtained 8 replicates. Also 3 replicates to measurement of total organic matter in sediments and determination of sediment granulation and determination of chlorophyll a and non-a pigments in sediment 
was carried out. The samples washed with sea water and sieve and after stabilization by formalin $4 \%$ was transferred to the laboratory.

The average frequency of species in each station was used to analyze the data. Also, in order to investigate the environmental factors on the frequency, first the diffraction homogeneity and the compliance of the data with the normal distribution were investigated by the Kolomogorov-Smirnov test. The population structure of macrobenthos communities between depths in 4 season were investigated by PERMANOVA test.

\section{RESULTS AND DISCUSSION}

In this study, a total of 10,472 people during 4 seasons and 7 stations were counted, which includes 22 species (table 2). In total, the highest percentage abundance of dominant macrobenthos communities during the sampling period including, Bivalves (40\%), Crustaceans (36\%), Annelids (22\%) and Gastropods (2\%) were observed (figure 2).

Table 2 - List of macrobenthos communities identified in sampling stations during the study period on the shores of Mazandaran year 2020

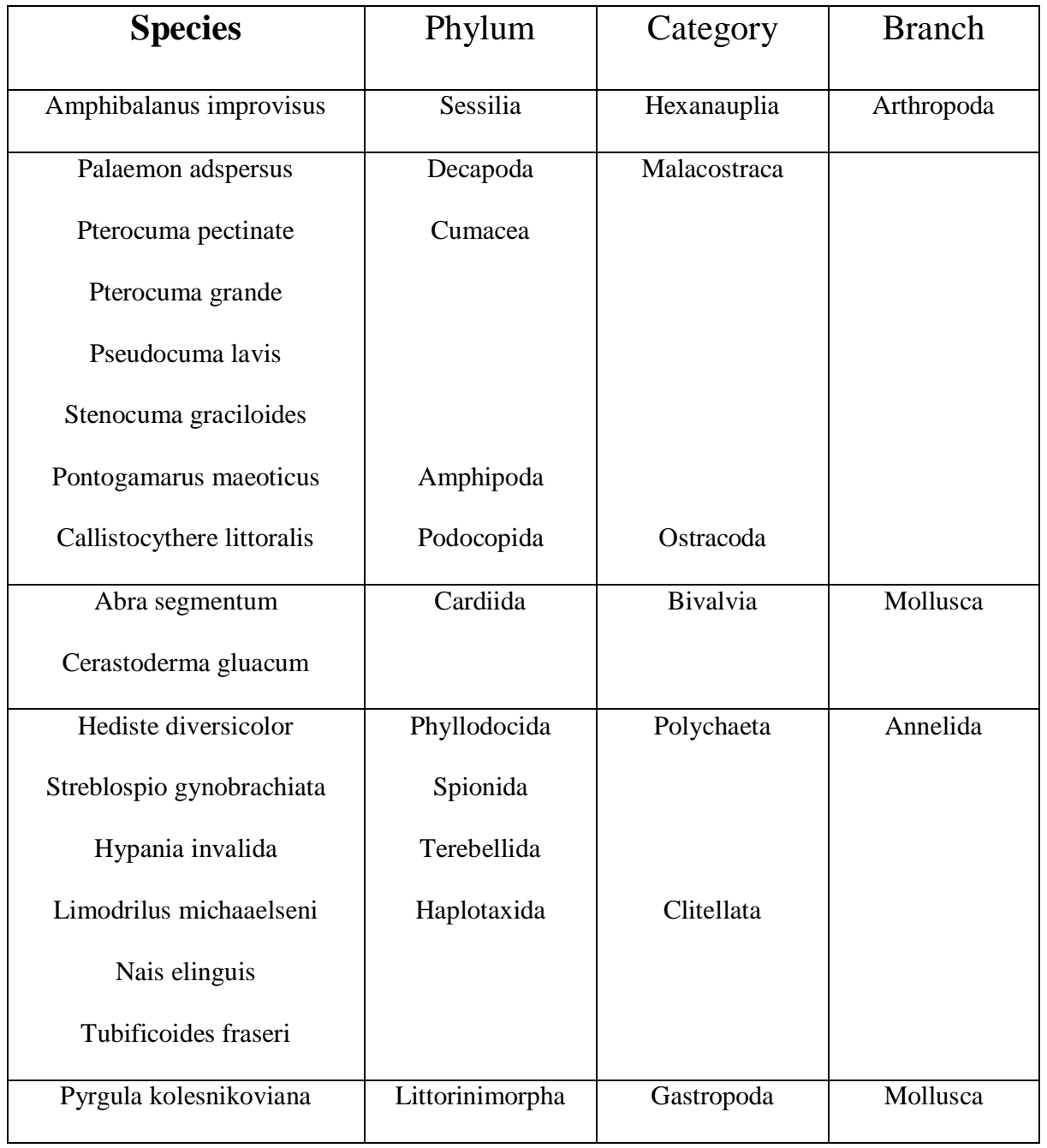




\begin{tabular}{|c|l|l|l|}
\hline Pyrgula nana & & & \\
Pyrgula schorygini & & & \\
Pseudamnicola brusiniona & & & \\
Pseudamnicoda exigua & & & \\
\hline Ammonia beccarii & Rotaliidae & Globothalamea & Foraminifera \\
\hline
\end{tabular}

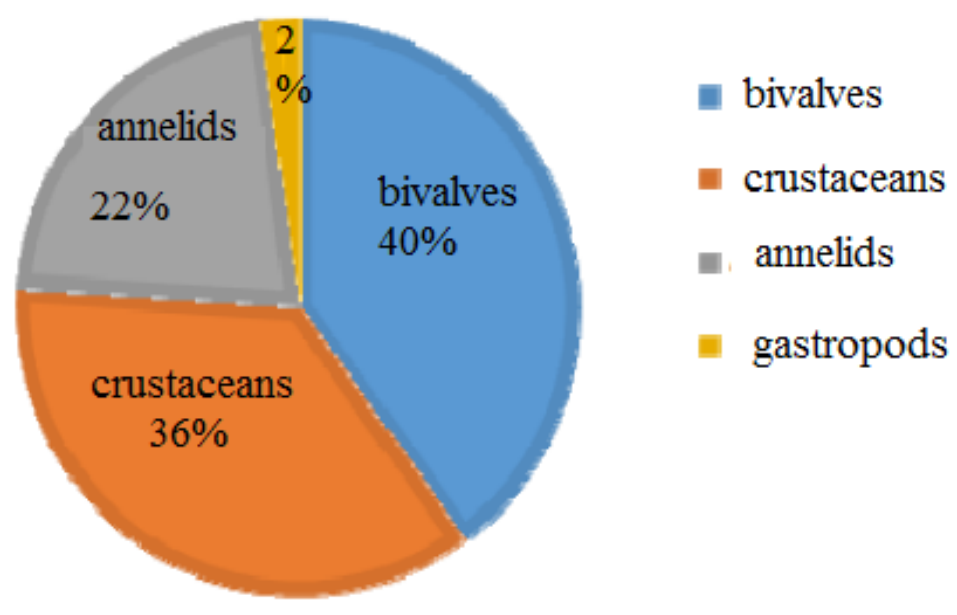

Figure 2 - Abundance of macrobenthos communities identified in sampling stations during the study period on the shores of Mazandaran year 2020

The highest abundance is at the station $7(648 \pm 170.79$ number $/ \mathrm{m} 2)$ in spring and the lowest is at the station $1(12 \pm 3.5$ number $/ \mathrm{m} 2)$ in winter. Also, the maximum and minimum amount of biomass in station $4(36.21 \pm 2.5 \mathrm{gr} / \mathrm{m} 2)$ in winter and station $1(0.01 \pm 0)$ is recorded, respectively (figure 3$)$. The results of PERMANOVA analysis showed that the effect of season and depth are significant in abundance, species richness and biomass, but its interaction in abundance, species richness and biomass is not significant (table 3).

Table 3: The results of PERMANOVA test to show difference in abundance, species richness and biomass of macrobenthos communities in different season and depth on the shores of Mazandaran year 2020

\begin{tabular}{|c|c|c|c|c|c|c|c|c|c|r|}
\hline & \multicolumn{5}{|c|}{ Abundance } & \multicolumn{3}{c|}{ Species richness } & \multicolumn{3}{c|}{ biomass } \\
\hline $\begin{array}{c}\text { Source of } \\
\text { changes }\end{array}$ & $\mathrm{df}$ & Ms & $\mathrm{F}$ & $\mathrm{P}$ & $\mathrm{Ms}$ & $\mathrm{F}$ & $\mathrm{P}$ & Ms & $\mathrm{F}$ & $\mathrm{P}$ \\
\hline season & 3 & 12654 & 21.615 & 0.0002 & 1804 & 11.56 & 0.0002 & 21357 & 12.02 & 0.0002 \\
\hline
\end{tabular}




\begin{tabular}{|c|c|c|c|r|r|r|r|r|r|r|}
\hline depth & 1 & 5238 & 8.947 & 0.0016 & 948.44 & 6.077 & 0.0122 & 8538.2 & 4.805 & 0.015 \\
\hline Season $\times$ & 3 & 662.36 & 1.131 & 0.335 & 125.97 & 0.807 & 0.489 & 2937.8 & 1.653 & 0.133 \\
depth & & & & & & & & & & \\
\hline error & 230 & 585.43 & & & 156.06 & & & 1776.9 & & \\
\hline total & 237 & & & & & & & & & \\
\hline
\end{tabular}

The results of PERMANOVA test showed that the season and depth factors and their interaction on species composition and the population structure of macrobenthos communities is significant (table 4).

Table 4: Analysis results PERMANOVA to show the difference in species composition of macrobenthos communities in different depths and seasons on the shores of Mazandaran year 2020

\begin{tabular}{|c|c|c|c|c|c|c|c|}
\hline & \multicolumn{6}{|c|}{ Species composition } & \multicolumn{3}{c|}{ Species structure } \\
\hline Source of changes & df & Ms & F & P & Ms & F & $\mathrm{p}$ \\
\hline season & 3 & $189 / 6$ & $30 / 392$ & $0 / 0002$ & $1663 / 3$ & $57 / 822$ & $0 / 0002$ \\
\hline depth & 1 & $39 / 11$ & $6 / 269$ & $0 / 0004$ & $300 / 94$ & $10 / 462$ & $0 / 0002$ \\
\hline Season $\times$ depth & 3 & $18 / 66$ & $2 / 992$ & $0 / 0018$ & $74 / 875$ & $2 / 603$ & $0 / 0278$ \\
\hline error & 230 & $6 / 23$ & & & $28 / 765$ & & \\
\hline total & 237 & & & & & & \\
\hline
\end{tabular}



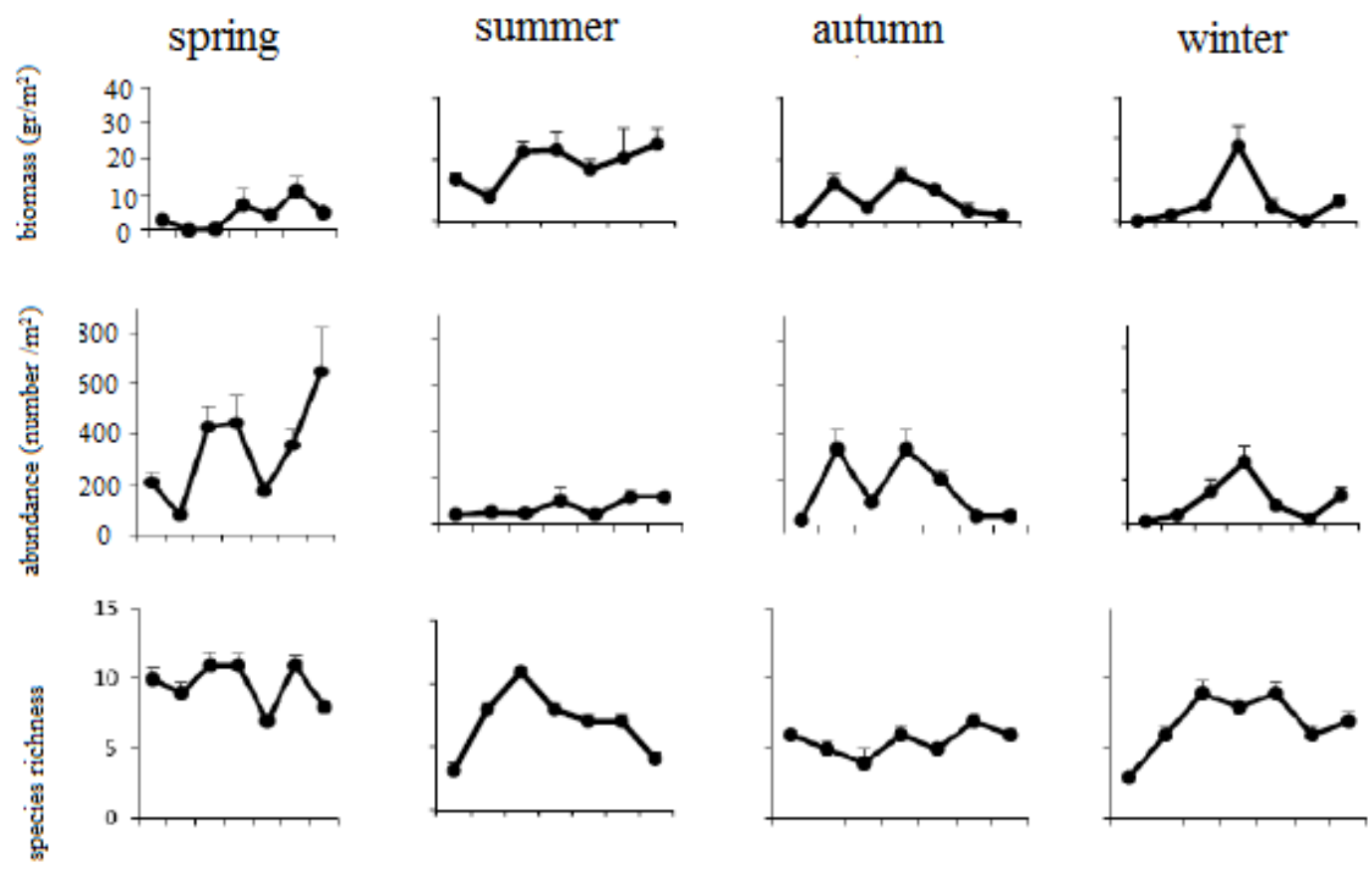

Figure 3: Biomass, abundance and species richness in sampling stations during the study period on the shores of Mazandaran per year 2020

Total abundance in stations with a 10 meters depth $(206.04 \pm 13.67)$ almost twice as many stations with a 5 meters depth $(100.88 \pm 16.46)$ was obtained. The results also showed that the richness of the total species has a significant difference between the two depths. This amount at a depth of 10 meters, 1.3 times greater than the depth 5 meters was observed.

\section{CONCLUSION}

The results of this study showed that in total the highest percentage abundance of macrobenthos communities during the Sampling period was observed in Bivalves, Crustaceans, Annelids, and Gastropoda. The results of the present study showed that with increasing depth from 5 to $10 \mathrm{~m}$, the abundance of macrobenthos communities in spring, summer, autumn and winter increased at the rate of 4 , 2, 1, 9 times, respectively. Also the values of species richness of benthos has been increasing in most stations.

Also in the present study, the amount of biomass in stations with the depth of 10 meters, except in autumn, was more than 5 meters depth. At shallow depths, the action of waves and currents is usually higher, which can probably cause bed instability and, as a result, affect the abundance and biomass of benthos.

The results of the present study show that benthic communities undergo major change with space and time. It is seemed that these changes are mostly influenced by factors such as temperature, depth. Moreover, the effect of other factors and their interaction with each other cannot be ignored.

Since the benthic communities in environmental bioassay studies at sea is commonly used. Therefore, the temporal and spatial nature of these communities should be known in order to identify the difference between these natural changes and the resulting changes of environmental stresses and pollution. 


\section{REFERENCES}

Negarestan, H., Hashemi motlagh, M.,(2020). Identification and study of macrobenthic assemblages of southwest coasts, Sustainability, Development and Environment, 2p.

Jalili, M., Negarestan, H., Safaeian, Sh., (2010) . Investigation of macrobenthic fauna in the southwestern part of Anzali wetland and their relationship with bedrock organic matter. Journal of Oceanography, 4p.

Kowsari, S., Vosoughi, A., Farabi, S., Soleimani Rudi, A.,(2009). Comparison of the abundance and biomass of Caspian Sea macrobenthos in the basin of Mazandaran province. Iranian Journal of Fisheries, 2, 119-128p.

Mirzajani, A., Ghaninejad, D., Ghasan Sasan Sarai, A,(2005). Relationship between coastal moth catch and the abundance of benthic invertebrates in the Caspian Sea in Guilan province. Research and Construction, 68p.

Ghasemi, A.F, Taheri, M, Yazdani Foshtomi, M, Noranian,M,(2016). Gorgan Bay: a microcosm for study on macrobenthos species-environment relationships in the southeastern Caspian Sea. Acta Oceanologica Sinica, 4, no. 82-88p.

Farshchi, M., Nasrolahi, A., Shokri, M.,(2018). Spatial and temporal variations of macrobenthic communities of the southern coast of the Caspian Sea, Pareh sar, Journal of Animal Research (Iranian Journal of Biology), 3p.

Chen, Kouping, Shengyan Tian, and Jiu Jimmy Jiao.(2010). Macrobenthic community in Tolo Harbour, Hong Kong and its relations with heavy metals. Estuaries and coasts 33, no: 600-608p.

Briggs, Kevin B., J. Kevin Craig, S. Shivarudrappa, and T. M. Richards. (2017). Macrobenthos and megabenthos responses to long-term, large-scale hypoxia on the Louisiana continental shelf. Marine environmental research 123: 38-52p.

Nicolaus, EE Manuel, Robin J. Law, Serena R. Wright, and Brett P. Lyons.(2015). Spatial and temporal analysis of the risks posed by polycyclic aromatic hydrocarbon. polychlorinated biphenyl and metal contaminants in sediments in UK estuaries and coastal waters. Marine pollution bulletin 95. no. 1: 469479 p.

Sánchez-Moyano, J. E., I. García-Asencio, and J. C. García-Gómez. (2010). Spatial and temporal variation of the benthic macrofauna in a grossly polluted estuary from southwestern Spain. Helgoland Marine Research.no. 3: 155-168p.

Zhang, Ying, Zhenbo Lv, Bo Guan, Yuanjin Liu, Fan Li, Shaowen Li, Yuanqing Ma, Junbao Yu, and Yunzhao Li.(2013). Status of macrobenthic community and its relationships to trace metals and natural sediment characteristics. CLEAN-Soil Air Water, no. 10: 1027-1034p.

Mulik, Jyoti, Soniya Sukumaran, and Tatiparthi Srinivas. (2020). Factors structuring spatio-temporal dynamics of macrobenthic communities of three differently modified tropical estuaries. Marine pollution bulletin 150: 110767p. 
Farshchi, Morteza, Ali Nasrolahi, and Mohammad Reza Shokri.(2020). Variability in benthic invertebrate community structure near warm water effluents of a power plant in the southern Caspian Sea. Regional Studies in Marine Science 40: 101507p.

Sowa, Agnieszka, and Mariola Krodkiewska.(2020). Impact of secondary alinization on the structure and diversity of oligochaete communities. Knowledge \& Management of Aquatic Ecosystems. 421:6p.

Tajri, M., Raziei, M., Afsa, S., Azimi, A., Shamkhi Ranjbar, Kh., Hami Tabari, A..(2014). Investigation of diversity. frequency and biomass of benthic wetlands in Gomishan wetland in Golestan province. Journal of Biology Animal, issue 3.

Asghari, S., Ahmadi, M., Mohammadizadeh, F., Keyvan, Ejlali,(2015). Investigation of the effects of some environmental factors on diversity and density of bivalves of the Iranian coasts of the Oman Sea. Research Journal.

Angulo-Preckler, Carlos, Fernando Tuya, and Conxita Avila.(2017). Abundance and size patterns of echinoderms in coastal soft-bottoms at Deception Island (South Shetland Islands, Antarctica). Continental Shelf Research. 137: 131-141p.

S. kosari, G.H. Vosoughi, S.M.V. Farabi,(2009). Comparison of the abundance and biomass of macrobenthos in the Caspian Sea in the basin of Mazandaran province, Iranian Scientific Fisheries Journal, issue 2.

S, Sharbati R. Akrami S. Yelghi,(2013). Identification, abundance and biomass of benthic communities in south east coasts of the Caspian Sea (Golestan Province), Iranian Scientific Fisheries Journal, issue 2.

Borhani Jelodar, M., Ismaili Jelodar, A., Jani Khalili, Kh.,(2010). Review Demographic changes depending on the depth of macrobenthos in the Caspian Sea in the coastal area of Babolsar. The first national-regional conference, Ecology of the Caspian Sea. Sari, June.

S. Kosari, R. Mousavi Nadushan, M.R. Fatemi, K. Ejlali Khanghah, A. Mashinchian.(2021). Macrobenthos as bioindicator of ecological status in the Yekshabe creek-estuary. Persian Gulf. Iranian Journal of Fisheries Sciences, 20. 